\title{
Biologic response of animals to husbandry stress with implications for biomedical models
}

This article was published in the following Dove Press journal:

Open Access Animal Physiology

30 July 2010

Number of times this article has been viewed

\section{Bernadette Earley \\ Kelly Buckham-Sporer \\ Sandeep Gupta \\ Wanyong Pang \\ Simon Ting}

Animal and Bioscience Research Department, Animal \& Grassland Research and Innovation Centre,

Teagasc, Grange, Dunsany,

Co. Meath, Ireland
Correspondence: Bernadette Earley Animal and Bioscience Research Department, Animal \& Grassland Research and Innovation Centre, Teagasc, Grange, Dunsany, Co. Meath, Ireland

$\mathrm{Tel}+35346906 \quad$ I 100

Fax +35 3469026154

Email bernadette.earley@teagasc.ie
Abstract: The quality of life of animals is defined by a range of parameters including health, physiology, and behavior. Stress is defined as any damaging strain, force, or agent which stimulates a physiologic defense reaction and is capable under certain circumstances of producing pathologic lesions. Disruption to normal homeostasis can impinge on other biologic processes such as metabolism, cardiovascular activity, immune function, and behavior. In general, chronic stress is considered to have a greater potential impact on animal health and welfare than acute stress, because the animals are exposed and reacting to the stressor(s) for longer periods, thereby causing prolonged disruption to homeostasis and related biologic processes. Impaired coping responses may trigger specific alterations in behavior, organ damage, reduced performance, increased susceptibility to disease, and subfertility. At a molecular level, immune function is mediated by the release of cytokines, nonantibody messenger molecules from a variety of cells of the immune system and from other cells, such as endothelial cells. Biochemical alterations in immune function are, in part, induced by plasma hormone concentration changes elicited by a stressor subsequent to activation of the sympathetic nervous system, the sympathetic adrenomedullary axis, and the hypothalamo-pituitary-adrenocortical axis.

Keywords: stress, inflammation, animal models, physiology, immunology, behavior

\section{Stress and disease}

It has long been observed that an association exists between stress and disease susceptibility in domestic farm animals, although a definitive causal factor has yet to be defined. Many researchers have implicated a suppression of the host's immune system by stress that allows opportunistic pathogens to invade. Furthermore, substantial evidence has suggested that this immunosuppression is mediated by glucocorticoids following hypothalamic-pituitary-adrenocortical (HPA) axis activation by a stressor. ${ }^{1}$ However, recent research has suggested that stress, and its association with increased glucocorticoid concentrations, is not solely immunosuppressive and may actually enhance immune function. ${ }^{2}$ In either case, susceptibility to disease may increase because neither inadequate nor excessive activation of immune components is ideal in the prevention of disease.

The immune system response is considered to be one of the most important complex pathways in the animal to enable it to defend itself against stressful environments and/or conditions, ${ }^{3,4}$ and to alleviate the increased incidence of diseases and suffering arising from stress in animals. The mechanisms responsible for combating stressful events involve "innate" and "acquired" immunity. Acquired immunity is evaluated by measuring an animal's cellular and/or humoral immune responses. Innate immunity includes 
factors such as phagocytic cells (neutrophils, monocytes, and macrophages), cells that release inflammatory mediators (basophils, mast cells, and eosinophils), natural killer (NK) cells, and molecular elements such as the complement system, acute phase proteins, and cytokines. Acquired or adaptive immunity consists of antigen-specific reactions through T- or B-cell lymphocytes and immunoglobulin components. In the presence of an antigen, B-cells proliferate and mature into plasma cells which secrete antibodies that bind specifically to that antigen. T-cell lymphocytes exhibit antigen specificity by activating macrophages or killing pathogens. T-cell lymphocytes can be classified as T-helper cells, T-suppressor cells, and cytotoxic T-cells. Activated T-cells secrete cytokines and modulate the immune system against specific antigens or stress stimuli. Major cytokines that attract and activate lymphocytes include interleukin (IL)-2, IL-6, tumor necrosis factor-alpha (TNF- $\alpha$ ) and interferon-gamma (IFN- $\gamma$ ). These cytokines may crossregulate with the growth and differentiation of their source (T-cell lymphocyte) and, therefore, affect further cytokine production. The production of these cytokines is modulated by neuroendocrine factors and plays a key role in immunosuppression by eliminating the antigen.

\section{Stressors in livestock beef production}

Stressors can be divided into those that are physical or environmental, and those that are psychologic or perceived, although many routine handling procedures can combine both. Examples of physical stressors are extreme temperature, feed and/or water deprivation, electric shock, pain, and disease. ${ }^{5,6}$ Psychologic stressors usually include the fear and/or novelty of deviations from a daily routine, restraint and/or isolation, unfamiliar sights and noises, and presence of perceived predators, including humans. ${ }^{6,7}$ Extensive research has shown that psychologic stressors can be equally or even more adverse than physical stressors. An animal's reaction to many of these stressors can be affected by the influences of genetics, previous handling and experience, the duration of the stressor, whether it is acute or chronic, and whether it is escapable or inescapable. ${ }^{6,9}$ Temperament has been found to be a highly heritable trait in cattle, ranging from 0.40 to 0.53 , and an inherited temperament for high excitability may affect an animal's response to handling practises. ${ }^{6}$ If an animal's memory of a novel event is one of fear and pain, it may react even more strongly to the same event in the future and may be extremely difficult or impossible to habituate to that event or procedure. ${ }^{6}$ Interestingly, it appears that an animal's perception of a stimulus as stressful is necessary to mount a stress response; activation of stress response systems does not occur if an animal does not perceive an event to be fearful or stressful. ${ }^{8}$ Husbandry management procedures, for example, castration, dehorning, and changes in their social and physical environment, may induce fear responses in animals. Fear is an emotion and thus by definition is punctual, whereas being fearful depends on the personality of the animal.

\section{Stress response}

Because stress occurs when an animal's homeostasis is disrupted, the stress response consists of a set of physiologic mechanisms designed to return to homeostasis. Two distinct systems link the initial perception of the stressor to this response, ie, the sympathetic adrenomedullary (SAM) axis and the HPA axis. Overall, both central and peripheral activation involves the orchestrated interplay of short-term (acute) behavioral and endocrine responses that prepare animals for an immediate response to environmental adjustment, whereas long-term (chronic) responses involve a substantial adjustment of neuroendocrine, immune, and metabolic responses to the stressor in the brain. The HPA axis responds to a variety of stressors by synthesizing and releasing four key hormones, namely, corticotrophin-releasing factor or hormone (CRH), arginine-vasopressin (AVP), adrenocorticotrophic hormone (ACTH), and glucocorticoids. Glucocorticoids serve as the final effectors of the HPA axis (shown in Figure 1) and are critically involved in modulating the response to any psychologic or physical stressors.

The physiologic responses of animals to stressors are largely mediated through the central and peripheral neuroendocrine pathways, culminating in profound alterations in the trafficking and functioning of blood leukocytes. ${ }^{9}$ Stress-induced changes in the numbers of various leukocyte subsets migrating from blood and functioning in secondary lymphoid tissues and peripheral tissue sites of infection are the main factors influencing spread of infection and disease susceptibility in animals. Unraveling the interactions between stress hormones and resulting changes in circulating immune cells is one of the greatest challenges in the leukocyte biology of stressed animals.

Recent major technical developments that enabled full sequencing of the human (http://www.ncbi.nlm.nih. gov/genome/seq/HsHome.shtml), mouse (http://ww.ncbi. nlm.nih.gov/genome/guide/mouse/index.html) and bovine (http://www.bovinegenome.org) genomes, and creation of large species-specific expressed sequence tag collections and resources, have opened the doors of opportunity for 




Figure I hypothalamus-pituitary-adrenal axis.

Abbreviations: $\mathrm{ACTH}$, adrenocorticotrophic hormone; $\mathrm{CRH}$, corticotrophin-releasing hormone.

understanding biologic processes at the most sophisticated level. Thus, biologic knowledge of the structure, physical location, and linkages of genes to one another has increased significantly over the past decade. The next major step is to use these genomic resources to elucidate specific genes and factors that are activated or suppressed by biologic scenarios relevant to health. A working hypothesis of such research is that coexpression/repression of specific gene sets occurs in a complicated but well coordinated and orchestrated manner to regulate metabolic pathways that affect cell differentiation and function (ie, phenotype). However, the gene leaders, gene followers, and various roles of the biologic orchestra are currently unknown for most cells in most events. The problem of determining which genes are expressed in functional ways during key physiologic stress events will increasingly be solved when researchers adopt functional genomics approaches to generate comprehensive gene expression data using well designed experiments. This is because innovative tools such as DNA microarrays and next-generation sequencing tools allow simultaneous monitoring of thousands of genes in a system, providing detailed documentation of gene expression patterns in cells as they respond to their biologic microenvironment. These tools are very powerful for gene discovery research related to the health and well being of humans and animals. It is vital that reliable and robust animal models upon which to base these gene expression studies are available.
Therefore, the ultimate goal of animal and veterinary researchers studying animal welfare is to find new ways to eliminate the negative effects of husbandry stress that impair the health and well being of farm animals whilst maintaining acceptable levels of productivity from those animals. However, almost nothing is understood about the complex physiologic processes that link husbandry stress with immunity, health, and well being. This has left animal producers and researchers ill-prepared to handle the chronic production diseases that occur in livestock, the economic losses endured by families who raise livestock for a living, and the consuming public who are increasingly vocal about the quality of life of farm animals and implications of this for food safety and quality.

\section{Castration stress}

The production of beef from castrated male cattle is still preferred in Ireland, and in numerous other countries, including the UK, US, Australia, and New Zealand. One of the main animal welfare concerns in beef production is that of pain and distress, especially pain inflicted by normal husbandry procedures other than common day-to-day stress in typical production. Castration is a husbandry procedure, which can cause pain and discomfort and, if done incorrectly, may result in subsequent health problems.

The legal requirement for the use of anesthesia for castration in cattle varies considerably between different countries, depending on the method involved and age of 
the animals. However, the precise scientific basis for setting the requirements is unclear, but it may in part be due to consumer-driven demand for improved farm animal welfare by reducing the pain caused by routine husbandry procedures such as castration. In Ireland, use of anesthesia is required for surgical/Burdizzo castration of cattle over six months of age (Protection of Animals [Amendment] Act 1965 [S.I. 10 of 1965]). ${ }^{10}$ In contrast, castration of calves without use of anesthesia must be done before they reach two months of age in the UK (Veterinary Surgeons Act 1966). ${ }^{11}$ In Ireland and the UK, rubber ring castration (or use of other devices for constricting the flow of blood to the scrotum) without use of anesthesia can only be performed in calves less than seven days of age. ${ }^{10,11}$ In New Zealand, cattle over nine months of age must be castrated using an effective anesthetic (Animals Protection Act 1960). ${ }^{12}$ In Germany, castration of cattle without use of anesthesia is allowed only in animals less than four weeks of age (Animal Welfare Act 1998). In Switzerland, castration of male cattle has been prohibited without anesthesia since September 2001 (Artikel 65 der Tierschutzverordnung vom 1 September 2001 [Article 65 of the Swiss Animal Protection Ordinance, Amendment 2001]). ${ }^{13}$ Furthermore, the use of elastic rings for castration of animals is forbidden in Germany and Switzerland. By contrast, there is no legal requirement for the use of anesthesia for castration in the US. ${ }^{14}$ In all of the countries mentioned above, where the administration of anesthesia is required for castration, the procedure must be done either by a veterinarian or under veterinary supervision.

Castration is performed on calves because it reduces management problems associated with aggressive and sexual behavior. ${ }^{15-19}$ However, from an animal welfare perspective, the inflammation and pain due to handling and tissue trauma are potent activators of the HPA axis ${ }^{19-26}$ and cause distress. The three main methods used to castrate calves are a rubber ring or latex band to restrict the flow of blood to the scrotum, ${ }^{21,27}$ bloodless castration by crushing the spermatic cords with the Burdizzo, ${ }^{28}$ and surgical castration. ${ }^{29}$
Systemic analgesia with a nonsteroidal anti-inflammatory drug (NSAID), ketoprofen, has been shown to be more effective than local or epidural anesthesia in modulating cortisol and inflammatory responses, and in the suppression of immune function. ${ }^{20}$ Ketoprofen effectively suppressed the surgical castration-induced peak cortisol response, and the 12-hour integrated cortisol response by $56 \%$ compared with surgery alone and by $40 \%$ compared with surgery under local anesthesia in 5.5-month-old Friesian calves. Furthermore, combined administration of ketoprofen and local anesthesia delayed the peak cortisol response by four hours relative to surgery and ketoprofen (Table 1 and Figure 2). However, the overall integrated cortisol response over 12 hours was greater than with ketoprofen treatment alone due to a delayed secondary peak in cortisol response. ${ }^{20}$ The reason for this was unclear. In contrast, others ${ }^{12}$ showed that combined local anesthetic and ketoprofen administration almost completely eliminated the peak and integrated plasma cortisol responses of two- to four-month-old Friesian calves to surgical castration.

Calves at 47 days of age have lower plasma cortisol responses to castration and the use of a NSAID is a better alternative to local anesthesia for the alleviation of inflammatory and pain-associated behavioral responses to castration. ${ }^{20,30,31}$ The findings showed that calves at 47 days of age exhibited lower stress responses (plasma cortisol and inflammatory responses) to Burdizzo castration compared with older calves (76 to 165 days of age). ${ }^{30,31}$

Previous studies have identified that cortisol per se may not be specifically responsible for reduced immune function following castration. ${ }^{25,26}$ Castration of cattle has an acute adverse effect on animal performance, cortisol response, and immune function and administration of local anesthesia to 5.5-month-old bull calves during Burdizzo castration induced scrotal swelling. ${ }^{20,24}$ Surgical castration induced greater peak and total cortisol responses than bloodless Burdizzo castration ${ }^{24}$ and thus was selected for use as a model to study the effects of the acute stress of castration on cortisol,

Table I Plasma cortisol concentrations of bull calves left untreated, surgically castrated, or surgically castrated following ketoprofen, local anesthetic administration, or surgically castrated following local anesthetic and ketoprofen ${ }^{20}$

\begin{tabular}{llllll}
\hline & Con & Surg & Surg + keto & Surg + LA & Surg + LA + keto \\
\hline AUC (ng/mL-I.h) & $56.8^{\mathrm{a}} \pm 5.37$ & $176.1^{\mathrm{d}} \pm 27.68$ & $78.1^{\mathrm{ab}} \pm 13.87$ & $130.8^{\mathrm{cd}} \pm 15.18$ & $117.6^{\mathrm{bc}} \pm 19.76$ \\
Peak (ng/mL) & $19.0^{\mathrm{a}} \pm 4.63^{\mathrm{a}}$ & $45.8^{\mathrm{b}} \pm 6.16^{\mathrm{b}}$ & $24.7^{\mathrm{a}} \pm 5.12^{\mathrm{a}}$ & $22.1^{\mathrm{a}} \pm 2.69^{\mathrm{a}}$ & $28.8^{\mathrm{a}} \pm 4.23^{\mathrm{a}}$ \\
Interval to peak (h) & - & $0.31^{\mathrm{a}} \pm 0.04^{\mathrm{a}}$ & $0.29^{\mathrm{a}} \pm 0.04^{\mathrm{a}}$ & $2.63^{\mathrm{b}} \pm 0.77^{\mathrm{b}}$ & $4.61^{\mathrm{b}} \pm 1.75^{\mathrm{b}}$ \\
\hline
\end{tabular}

Notes: ${ }^{a, b, c, d}$ Within row $P<0.05$. Values expressed as mean \pm standard error.

Abbreviations: AUC, area under the curve; con, untreated controls; keto, ketoprofen; surg, surgically castrated; LA, local anesthetic. 


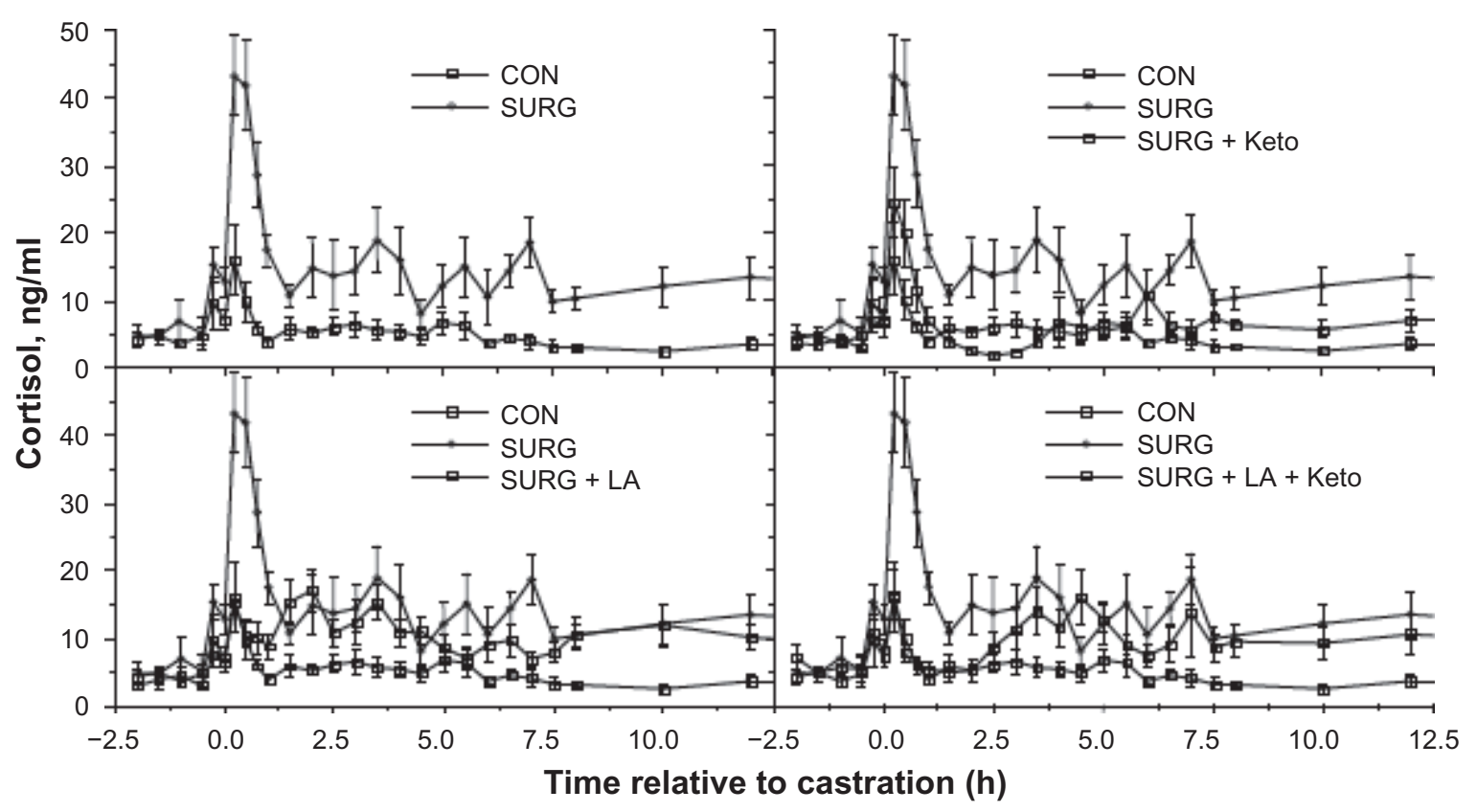

Figure 2 Mean \pm SE cortisol concentrations for bull calves left untreated (CON), surgically castrated (SURG), surgically castrated following ketoprofen (SURG + Keto), surgically castrated following local anesthetic and ketoprofen (SURG + LA + Keto). Copyright (c) 2002. Earley B, Crowe MA. Effects of ketoprofen alone or in combination with local anesthesia during castration of bull calves on plasma haptoglobin, in vitro interferon-G production, white blood cell numbers and animal performance. J Anim Sci. 2002;80:1044-1052. ${ }^{20}$

and immune and performance responses. Surgical castration induces greater peak and total cortisol responses than the Burdizzo method ${ }^{20,24,32-35}$ The administration of ketoprofen, local or caudal epidural anesthesia reduced $(P<0.05)$ the peak cortisol response to Burdizzo castration, but only ketoprofen was effective $(P<0.05)$ in minimizing the integrated cortisol response when compared with castration alone and castration with local or caudal epidural anesthesia ${ }^{33}$ (Figure 3). There is a general perception that delaying castration could extend the production advantages of keeping animals as bulls until weaning or beyond puberty. However, a number of studies have shown that there is no advantage in delaying castration of bulls from birth up to 17 months of age in terms of live weight, growth rate, or carcass weight at slaughter. Burdizzo castration of spring-born calves in their first autumn at five to six months of age was reported to have no effect on the overall 347-day live weight gain compared with delayed unilateral castration (the right testicle removed in autumn and left testicle the following spring with approximately 178 days apart) or complete castration in spring with about a one-month interval between each side of the testicle. Furthermore no interaction was reported between castration treatment and breed type (Friesian versus Charolais $\times$ Friesian). ${ }^{36}$ The effects of time of complete or split castration on performance of beef cattle were investigated at Teagasc, Grange Beef Research Centre. In one experiment, 144 Friesian and Charolais $\times$ Friesian calves (mean live weight $214 \mathrm{~kg}$ ) at pasture were assigned to three castration treatments, ie, complete castration in autumn, split castration (right testicle in autumn and left in spring), and complete castration in spring. There was no significant effect of castration treatment on live weight gains to the



Figure 3 Mean \pm SE plasma cortisol concentrations for bull left untreated $(\square)$, Burdizzo castration (o), Burdizzo castration following ketoprofen administration ( $\bullet$ ), Burdizzo castration following lidocaine local anesthesia $(\Delta)$, or burdizzo castration following combined xylazine and lidocaine caudal epidural anesthesia $(\bullet)$; $n=9$ for group $C$, and $n=10$ for the remaining treatment groups. The integrated plasma cortisol responses (area under the curve) were greater $(P<0.05)$ in all castrated animals than in control bulls. The administration of ketoprofen, local or caudal epidural anesthesia reduced $(P<0.05)$ the peak cortisol response to castration, but only ketoprofen was effective $(P<0.05)$ in minimizing the integrated when compared with castration alone, castration with local or caudal epidural anesthesia. Copyright (c) 2003. Ting STL, Earley B, Hughes JM, Crowe MA. Effect of ketoprofen, lidocaine local anesthesia, and combined xylazine and lidocaine caudal anesthesia during castration of beef cattle or stress responses, immunity growth, and behavior. J Anim Sci. 2003;81:1281-1293. ${ }^{33}$ 
end of the second grazing season. In a second experiment, 72 Charolais $\times$ Friesian calves (mean live weight $241 \mathrm{~kg}$ ) at pasture were assigned to low (silage only) or high (silage and $2 \mathrm{~kg}$ of concentrates per head daily) feeding levels in winter using the castration procedures described in the first experiment. They were then turned out to pasture for a 181-day grazing season. It was concluded that neither time of castration nor splitting of castration significantly affected live weight at the end of the second grazing season. ${ }^{36}$

Burdizzo and banding castration methods using 12-month old bulls showed that both castrate groups lost in excess of $1.0 \mathrm{~kg} /$ day in the first two weeks after castration. ${ }^{31}$ Intact bulls lost $0.49 \mathrm{~kg} /$ day, which is typical for this type of animal going to grass. Overall, intact bulls grew faster than castrates and performed better than those undergoing either castration treatment.

\section{Weaning stress}

In suckler herds, calves remain with the dam at pasture until they are five to nine months old, at which time they are separated from the dam. Weaning of the suckled calf from its dam can be stressful for the calf. In addition to removal from the dam, the weaning procedure may be compounded by other stressors, eg, change of diet (grass and milk to conserved feed [EG, silage] with or without concentrates), change of environment (outdoors to indoors), transport/marketing, dehorning, and castration. Weaning therefore, is a multifactorial stressor, in which, nutritional, social, physical, and psychologic stressors are combined. Psychologic stress is present in the form of maternal separation $^{37}$ and social disruption, ${ }^{38,39}$ whereas physical and nutritional stressors are often present in the introduction of and adaptation to a novel diet and a novel environment. ${ }^{40}$

Previous studies have examined the effect of maternal separation under varying management regimes on calf behavior, ${ }^{41}$ plasma acute-phase protein concentrations, ${ }^{42}$ and neutrophil:lymphocyte $(\mathrm{N}: \mathrm{L})$ ratio. ${ }^{43}$ The results have indicated that breaking the maternal bond is stressful to the calf. Management of the calf at weaning can influence its susceptibility to disease, and situations of stress have previously been associated with attenuation of immune function. ${ }^{3,44}$ No effect of late weaning on the humoral immunity of weaned calves has been reported. ${ }^{45}$ Attenuation of cell-mediated ${ }^{46,47}$ but not humoral immunity ${ }^{25}$ has been identified in situations of chronic stress. Cell-mediated rather than humoral immunity may be a more reliable indicator of the physiologic status of calves older than five months. ${ }^{48}$ The adrenal hormones are recognized indicators of stress in bovine models ${ }^{49}$ but no work has been identified which describes the long-term effect of weaning on the mediators of stress.

The effect of the combined psychologic and nutritional stress of maternal separation on the physiologic mediators of stress (cortisol, adrenaline, and noradrenaline) and measures of immune function (in vitro IFN- $\gamma$ production, NL ratio and acute-phase protein concentrations) was measured in calves. ${ }^{47}$ Thirty-eight male and 38 female Continental calves were habituated to handling for two weeks prior to bleeding. Calves were blocked on sex, weight, and breed of dam and randomly assigned, within block, to either a control (C, cows remain with calves) or abruptly weaned group (W, calves removed from cows). Animals were allocated to the respective

Table 2 The effect of time of sampling, weaning, and calf sex on plasma noradrenaline concentration and in vitro IFN- $\gamma$ response to the novel mitogens Con-A and $\mathrm{KLH}^{47}$

\begin{tabular}{|c|c|c|c|c|c|c|c|c|c|c|c|c|}
\hline & \multirow{3}{*}{$\begin{array}{l}\text { Sex (S) } \\
\text { Wean }(W) \\
\text { Time (T) }\end{array}$} & \multicolumn{2}{|l|}{ Male } & \multicolumn{2}{|l|}{ Female } & \multicolumn{7}{|c|}{ Statistical result } \\
\hline & & Control & Wean & Control & Wean & & $\mathbf{T}$ & $\mathbf{S}$ & $\mathbf{W}$ & $\mathbf{T} \times \mathbf{S}$ & $\mathbf{T} \times \mathbf{W}$ & $\mathbf{S} \times \mathbf{W}$ \\
\hline & & & & & & & & & & & & \\
\hline \multirow{3}{*}{$\begin{array}{l}\text { Noradrenaline } \\
\text { (nmol/L) }\end{array}$} & 24 & 3.68 & 7.14 & 5.56 & 6.76 & F value & 0.498 & 0.625 & 0.001 & 0.012 & 0.498 & 0.046 \\
\hline & 48 & 4.32 & 8.02 & 5.98 & 6.58 & SED & 0.444 & 0.684 & 0.684 & 0.855 & 0.855 & 0.967 \\
\hline & 168 & 3.89 & 8.6 & 3.59 & 5.16 & & & & & & & \\
\hline \multirow[t]{4}{*}{ Con-A } & -168 & 1.05 & 0.89 & 1.33 & 1.10 & F value & 0.001 & 0.222 & 0.176 & 0.442 & 0.843 & 0.973 \\
\hline & 24 & 0.85 & 0.64 & 0.84 & 0.94 & SED & 0.082 & 0.108 & 0.108 & 0.148 & 0.148 & 0.152 \\
\hline & 48 & 0.86 & 0.58 & 0.73 & 0.68 & & & & & & & \\
\hline & 168 & 0.64 & 0.72 & 1.05 & 0.64 & & & & & & & \\
\hline \multirow[t]{4}{*}{$\mathrm{KLH}$} & -168 & 0.48 & 0.32 & 0.51 & 0.42 & F value & 0.001 & 0.847 & 0.01 & 0.384 & 0.569 & 0.697 \\
\hline & 24 & 0.44 & 0.07 & 0.33 & 0.11 & SED & 0.046 & 0.087 & 0.087 & 0.103 & 0.103 & 0.122 \\
\hline & 48 & $0.4 \mathrm{I}$ & 0.11 & 0.20 & 0.11 & & & & & & & \\
\hline & 168 & 0.21 & 0.06 & 0.29 & 0.08 & & & & & & & \\
\hline
\end{tabular}

Abbreviations: SED, standard error of the difference; IFN- $\gamma$, interferon gamma; KLH, keyhole limpet hemocyanin; con-A, concavalin-A. 
treatment groups at weaning ( 0 hours). Calves were bled at - 168, 6 (males only), 24, 48, and 168 hours postweaning. At each sampling time, an observer scored the behavioral reaction of calves to sampling. Blood samples were analyzed for cortisol, and catecholamine concentrations (not sampled at 168 hours), and in vitro IFN- $\gamma$ production, NL ratio, and acute-phase protein concentrations. There was no effect of weaning or sex on calf behavioral reaction to handling. Assignment of animals to treatment groups at 0 hours, and hence disruption of the established social group, increased $(P<0.001)$ the plasma cortisol concentration and $\mathrm{N}: \mathrm{L}$ ratio, and reduced the leukocyte concentration $(P<0.001)$ and in vitro IFN- $\gamma$ response to the mitogen concanavalin-A (Con-A, $P<0.001$ ) and keyhole limpet hemocyanin (KLH, $P<0.001$, Tables 2 and 3). Plasma adrenaline and noradrenaline concentrations were not affected by group disruption, weaning, or sex. There was a significant weaning $\times$ sex and time $\times$ sex effect on the noradrenaline response. The response increased for male calves with weaning and increased with each sampling time postweaning. For heifers, the response was not affected by weaning, and plasma concentrations decreased at 168 hours postweaning. There was no effect of weaning or sex on leukocyte concentration. There was a significant effect of weaning and sex on the $\mathrm{N}: \mathrm{L}$ ratio. Weaning significantly decreased the in vitro IFN- $\gamma$ response to the KLH mitogen. There was a significant time $\times$ weaning $\times$ sex interaction for fibrinogen concentration, but no effect of treatment on haptoglobin concentration. Abrupt breaking of the mother/offspring bond at weaning causes acute emotional, physical, and psychologic stress ${ }^{38,50}$ with accompanying immunosuppression. ${ }^{47}$ Impulses from sympathetic nerve fibers cause the release of adrenaline and noradrenaline from the medullae of the adrenal glands and directly innervate many other organs including the skin, heart, skeletal muscles, and lymphoid organs. ${ }^{51}$ The IFN- $\gamma$ response was attenuated by social group disruption, and by weaning for the KLH response only. The production of IFN- $\gamma$ is associated with subsets within the CD4 T-lymphocyte family. ${ }^{52}$ Production of the cytokine is stimulated by mitogen challenge. The KLH mitogen is a nonspecific immune response modifier, which can induce both a cell-mediated and a humoral response, ${ }^{53}$ while Con-A induces T-cell proliferation, evident from the higher in vitro response of IFN- $\gamma$ to the novel challenge in this study. Although the cortisol concentrations recorded in the study were within the diurnal variations in peripheral cortisol ${ }^{54}(1-17 \mathrm{ng} / \mathrm{mL})$, the increase from 7.4 to $14.2 \mathrm{ng} / \mathrm{mL}$ recorded during group disruption was associated with the decrease in cell-mediated immune function. The continued elevation of the cortisol response was also associated with the continued attenuation of both the Con-A and KLH responses. It is possible that an alteration in the lymphocyte concentration and conceivably subpopulation

Table 3 The effect of time of sampling, weaning, and calf sex on measures of the leukocyte population and plasma noradrenaline concentration $^{47}$

\begin{tabular}{|c|c|c|c|c|c|c|c|c|c|c|c|c|}
\hline & \multirow{2}{*}{$\begin{array}{l}\frac{\text { Sex }}{\text { Wean }} \\
\text { Time }\end{array}$} & \multicolumn{2}{|l|}{ Male } & \multicolumn{2}{|l|}{ Female } & \multicolumn{7}{|c|}{ Statistical result } \\
\hline & & Control & Wean & Control & Wean & & Time (T) & Sex (S) & Wean (W) & $\mathbf{T} \times \mathbf{S}$ & $\mathbf{T} \times \mathbf{W}$ & $\mathbf{S} \times \mathbf{W}$ \\
\hline White blood cells & -168 & 10.4 & II.I & II.I & II.4 & & & & & & & \\
\hline \multirow[t]{3}{*}{$\left(\times 10^{6} / \mathrm{L}\right)$} & 24 & 12.0 & 12.7 & II.4 & 12.2 & F value & 0.001 & 0.915 & 0.491 & 0.132 & 0.216 & 0.684 \\
\hline & 48 & 12.0 & 11.9 & 11.7 & 12.1 & SED & 0.25 & 0.43 & 0.43 & 0.52 & 0.52 & 0.60 \\
\hline & 168 & 11.7 & 10.8 & $\mathrm{II} .4$ & II.7 & & & & & & & \\
\hline \multirow[t]{4}{*}{ \% Neutrophils } & -168 & 26.5 & 28.8 & 25.3 & 23.7 & & & & & & & \\
\hline & 24 & 28.0 & 34.9 & 25.4 & 31.8 & F value & 0.008 & 0.011 & 0.001 & 0.747 & 0.005 & 0.090 \\
\hline & 48 & 28.2 & 34.5 & 26.4 & 28.6 & SED & $\mathrm{I} .44$ & 1.49 & 1.49 & 2.31 & 2.31 & 2.10 \\
\hline & 168 & 25.4 & 41.9 & 25.6 & 30.1 & & & & & & & \\
\hline \multirow[t]{4}{*}{ \% Lymphocytes } & -168 & 70.1 & 66.7 & 70.9 & 72.4 & & & & & & & \\
\hline & 24 & 68.2 & 60.4 & 71.1 & 65.0 & F value & 0.001 & 0.024 & 0.001 & 0.247 & 0.023 & 0.171 \\
\hline & 48 & 67.7 & 60.6 & 69.4 & 67.5 & SED & 0.99 & 1.27 & 1.27 & 1.76 & 1.76 & 1.80 \\
\hline & 168 & 70.9 & 64.4 & 70.3 & 66.2 & & & & & & & \\
\hline \multirow[t]{4}{*}{$\mathrm{N}: \mathrm{L}$ ratio } & -168 & 0.42 & 0.47 & 0.37 & 0.34 & F value & 0.008 & 0.025 & 0.003 & 0.215 & 0.077 & 0.328 \\
\hline & 24 & 0.44 & 0.61 & 0.36 & 0.51 & SED & 0.027 & 0.030 & 0.030 & 0.045 & 0.045 & 0.042 \\
\hline & 48 & 0.44 & 0.59 & 0.39 & 0.44 & & & & & & & \\
\hline & 168 & 0.36 & 0.47 & 0.37 & 0.46 & & & & & & & \\
\hline
\end{tabular}

Abbreviations: SED, standard error of the difference; N:L ratio, neutrophil:lymphocyte ratio. 
profiles, was associated with the glucocorticoid response at group disruption, ${ }^{55}$ although the influence of glucocorticoids on cell-mediated immunity per se has been questioned..$^{25,55}$ It has been proposed that catecholamine production can influence immune function both at the tissue and cellular level via innervation and receptors, respectively. ${ }^{56-58}$ Both noradrenaline levels and IFN- $\gamma$ production in response to KLH were influenced by weaning. However, the lack of a significant sex effect on the KLH response would question if the continued increase in noradrenaline levels for bulls may be associated with the depression. Because KLH is a nonspecific mitogen, its peripheral effects may therefore be associated with B-cell function. However, previous studies have shown no effect of chronic stress ${ }^{25}$ or weaning stress ${ }^{45}$ on humoral immunity post-KLH challenge. The effect of weaning was also associated with alterations in acute-phase protein production because plasma fibrinogen was sensitive to calf weaning and sex. Weaned bulls had a higher plasma fibrinogen concentration compared with all other groups but, like other groups, the plasma concentrations had returned to, or were less than, preweaning values by 168 hours. Increases in acute-phase protein production have been reported in models of castration ${ }^{20,25}$ and transport. ${ }^{42}$ In the latter study, the authors found no effect of genotype on fibrinogen concentrations when examining the physiologic response of calves to weaning and transport. In the present study, haptoglobin concentrations were not affected by treatment.

Mixing of weanlings from different sources is likely to cause bovine respiratory disease (BRD) when compounded with other stressors. ${ }^{47}$ The underlying cause of BRD in weaned calves is extremely complex, with the involvement of viruses, bacteria, and mycoplasma. The main viruses isolated from outbreaks of calf pneumonia have been infective bovine rhinotracheitis, respiratory syncytial virus, parainfluenza-3 virus, and bovine virus diarrhea/mucosal disease. In most cases it would appear that the primary infective agent is viral, producing respiratory tract damage that is subsequently extended by mycoplasmas and secondary bacterial infections, eg, Pasteurella sp. Factors affecting the calf's ability to fight infection include stress, overcrowding, inadequate ventilation, draughts, fluctuating temperatures, poor nutrition, and/or concurrent disease. Suckled calves eating $1 \mathrm{~kg}$ of concentrates/day in the 5-6 week period before weaning are less stressed than calves that have not been introduced to meals.

Bonding behavior between dam and calf, and between calves within social groups, has been established through behavioral observation. The stability of maternal ${ }^{59}$ and social counterpart $^{38}$ relationships are important for young calves. Abrupt weaning not only disrupts the maternal bond between the calf and its dam, but also the social bond between the animal and their familiar social group.

\section{Transportation stress}

Transportation of livestock involves several potential stressors that result in increased cortisol levels, ${ }^{60-64}$ mobilization of energy and protein metabolism, ${ }^{66}$ and a challenged immune system, ${ }^{3,67-72}$ resulting in increased disease susceptibility. Studies have been carried out to determine the optimum stocking density, the maximum duration of transportation, the timing of rest stops and which components of the transport process are the most stressful to cattle..$^{40,60-63,73-75}$ Physical factors such as noise and vibration, psychological/emotional factors such as unfamiliar environment or social regrouping, and climatic factors such as temperature and humidity, are also involved in the transport process. The transport of livestock can have major implications for their welfare, and there is strong public interest and scientific endeavor aimed at ensuring that the welfare of transported animals is optimal. ${ }^{76}$ Steers (aged 12-18 months) transported by road for 5, 10, and 15 hours lost $4.6 \%, 6.5 \%$, and $7.0 \%$ of their live weight, respectively, and recovery to pretransport live weight took five days. ${ }^{77}$ There are limited scientific data on the physiologic and hematologic recovery of animals after long durations of transport and, in particular, the physiologic recovery of animals during the 24-hour period posttransport.

The behavioral, physiologic, and immunologic consequences of animal transport research with relevance to the dairy industry have been summarized, and the conclusion is that the duration of the journey has a greater impact than the distance travelled on young calves, and that after long transport, most animals drink and then rest. ${ }^{78}$ Studies have also shown that young calves habituate to transport, unlike cows. The physiologic and behavioral consequences of transport of heifers, bulls, and steers by road from northern Germany to Mediterranean ports was examined and the authors concluded that animals should be prepared carefully pretransport, ie, with reference to energy and fluid balance, and be fed at sufficient time intervals during the journey to maintain physiologic homeostasis and expression of normal behavior. $^{79}$

The effects of space allowance during transportation and duration of a mid-journey lairage period on measures of stress, injury, dehydration, food restriction, and rest was investigated in young calves. ${ }^{80}$ The authors concluded that the duration of the mid-journey lairage was not an important 
factor, and while there was little evidence that transport affected immunologic variables, there was evidence to indicate the health of the calves was adversely affected posttransport. While studies have reported that confining animals on a moving vehicle is the most stressful component of transportation, ${ }^{60,61}$ other studies have reported that loading and unloading cause the most stress to cattle. ${ }^{65}$

The effects of fasting animals for eight hours prior to an eight-hour road journey and their ability to cope with the stress of transport was investigated, and the authors concluded that there was no significant difference in rectal body temperature pre- and posttransport and there were no significant differences in live weight on days 0 (pretransport), and on days 1, 4, and 10 (posttransport). ${ }^{62}$ Bulls (230 kg) undergoing an eight-hour transportation at stocking densities of $0.82 \mathrm{~m}^{2} /$ animal showed physiologic and hematologic responses that were within normal referenced ranges. ${ }^{63}$

It is well established that transportation of cattle is a stressor that causes a quantifiable response; however, excessive stress during transport resulting in physiologic or pathologic changes can be reduced with good management practises. ${ }^{64}$ Transportation can combine physical and psychologic stressors, and weaning, adverse handling during loading and unloading, comingling of unfamiliar animals, loud noises, overcrowding, food and water deprivation, extreme temperature, and the novelty of the truck or new feedlot facility can be individually stressful, let alone in combination with each other. ${ }^{7,74,81,82}$ While some authors have observed that being confined on a moving vehicle is the most stressful component of transportation, ${ }^{60,61}$ others contend that loading and unloading cause the most stress to cattle. ${ }^{65}$

Measurements of transportation stress encompass physiologic and behavioral measurements. Circulating cortisol as an indicator of HPA axis activation is clearly the most commonly utilized measurement, and increases have been observed in nearly all transportation studies of cattle compared with pretransportation concentrations or those obtained from nontransported cattle. ${ }^{60,68,73-75,81,83-86}$ The highest levels observed were $51.0 \mathrm{ng} / \mathrm{mL}$ after four hours in Holstein steers ${ }^{68}$ and $84.9 \mathrm{ng} / \mathrm{mL}$ in lactating Holstein $\times$ Friesian cows after two hours of transportation. ${ }^{87} \mathrm{~A}$ decrease in glucocorticoid and $\beta$-adrenergic receptor expression in lymphocytes has been observed, and measurement of these receptors has been suggested as a more reliable indicator of stress than measurement of their corresponding stress hormones. ${ }^{88}$ Indicators of activation of the SAM axis are seldom used, although increases in plasma adrenaline and noradrenaline have been observed in transported calves..$^{50,89,90}$
Markers of altered protein, energy, and mineral metabolism in cattle as well as rumen function have all been investigated during transportation stress. An alteration in protein metabolism is evidenced by changes in circulating total protein, albumin, and urea, which are usually increased. ${ }^{62,63,74,75,81,84,86}$ Altered energy metabolism may be marked by increases in blood glucose, ${ }^{60,74,81,85}$ lactate dehydrogenase, glutamic pyruvic transaminase, and glutamic oxaloacetic transaminase, ${ }^{84}$ and decreases in $\beta$-hydroxybutyrate. ${ }^{62}$ An increase in energy metabolism is a hallmark of the stress response as the body prepares to react to a potentially dangerous situation. ${ }^{91}$ Changes in mineral metabolism of calcium, copper, iron, magnesium, inorganic phosphorus, potassium, and zinc were not found, ${ }^{84}$ while others observed a decrease in circulating calcium following transportation. ${ }^{86}$

Changes in growth, weight, and feed intake have been investigated following transportation. Weight loss of up to $11 \%$ in total body weight has been observed in many transportation studies, which is attributed to loss of gut fill, urination, dehydration, and fasting. ${ }^{74,75,81,83,84}$ Dry matter intake may not be affected after transportation. ${ }^{83}$ In addition, transportation to the slaughter plant can affect subsequent carcass yields and meat quality. The loss of live weight during transportation results directly in decreased hot carcass weights, especially at high stocking densities. ${ }^{64,74}$ Plasma creatine kinase is often monitored as an indicator of muscle breakdown and bruising and is frequently elevated, ${ }^{62,63,81,84}$ by as much as $818 \%$ with long distance transportation. ${ }^{75}$ Bruising that occurs during transit reduces meat quality, and carcass bruise scores have been observed to increase linearly with stocking density. ${ }^{75}$ Furthermore, fasting and physical stress during transportation prematurely deplete muscle glycogen which is necessary for conversion to lactic acid and subsequent $\mathrm{pH}$ decrease in the meat after slaughter. ${ }^{64}$ High meat $\mathrm{pH}$ has been observed after transport to slaughter and is associated with reduced shelf-life and the incidence of "dark cutting" or "dark, firm, and dry" meat. ${ }^{74,75}$

Alterations in calf immunity are of great importance following transportation stress because these alterations are thought to be associated with increased incidence and severity of respiratory diseases. ${ }^{3}$ Most measures of immunologic changes relate to immune cell numbers in the blood and immune cell function. Most studies observe a leukocytosis marked by neutrophilia, which may occur in conjunction with a decrease in the number of other cells (lymphopenia, eosinopenia). ${ }^{3,68,75}$ On a related note, hematocrit levels are elevated with transportation in association with higher erythrocyte counts in the circulation. ${ }^{75,86}$ 
Other measures include the function of cells involved in innate immunity. Bovine alveolar macrophages, isolated from bronchoalveolar lavage fluid, have a reduced respiratory burst function after four hours of transportation. ${ }^{92}$ The respiratory burst function is necessary to produce reactive oxygen species that are toxic to phagocytosed pathogens, and these results may represent impaired lung defense. In contrast, enhanced respiratory burst activity has been found in neutrophils of transported calves. ${ }^{68}$ Decreased apoptosis of neutrophils in combination with increased migratory capacity in dairy cows was reported after four hours of transportation, supporting a potential enhancement of immune function. ${ }^{87}$

Additional observations include differences in the adaptive immune response. A decrease in lymphocyte blastogenesis or cytokine production in response to an antigen has been observed..$^{3,68,73,75,85}$ Others have observed that lymphocytes produce the stress hormone ACTH and that long-term transportation increased this production. ${ }^{93}$ Interestingly, IgG1 concentrations were elevated in transported calves compared with nontransported controls, ${ }^{45}$ indicating a possible enhanced function of the B-lymphocyte subset. This possible enhancement of components of immune function is supported by increases in NK cell counts and expression of major histocompatibility complex class II (MHC-II) in lymphocyte cell subtypes. ${ }^{94}$ Another marker of inflammatory response is the release of acute-phase proteins. These proteins are secreted by hepatocytes in response to injury, trauma, or infection and may be directly stimulated by glucocorticoids. ${ }^{95}$ Their presence in the circulation may be an excellent biomarker of inflammation because they are readily measurable in serum or plasma, and may even discriminate between acute and chronic inflammation in cattle. ${ }^{96}$ Results in the literature concerning changes in acute-phase protein concentrations during transportation stress are variable. Serum haptoglobin was elevated in calves transported for two days and was negatively correlated with lymphocyte function. ${ }^{97}$ In a separate experiment of transporting bulls at different stocking densities, plasma haptoglobin concentrations were unchanged, while plasma fibrinogen levels were reduced. ${ }^{62,63}$ In another study, plasma fibrinogen was greatly increased by long distance transportation. ${ }^{75}$ Fibrinogen, ceruloplasmin, serum amyloid-A, and $\alpha$-acid glycoprotein were assayed in the plasma of transported and comingled calves and found to be increased posttransportation; however, haptoglobin concentrations were higher in nontransported versus transported calves. ${ }^{83}$
An additional inflammatory measure is oxidative stress. Oxidative stress is marked by an imbalance of reactive oxygen species produced by metabolic and inflammatory reactions and the antioxidants that neutralize these species. Oxidative stress can cause severe tissue damage, altered metabolism, and impaired reproduction in dairy cows. ${ }^{98}$ Attenuated antioxidant capacity and elevated lipid peroxidation were observed in transported calves in association with respiratory disease, ${ }^{99}$ indicating that the calves may be under oxidative stress. The wide range of results reviewed here concerning inflammatory measures affected by transportation stress supports a growing suspicion that stress may not be entirely immunosuppressive. ${ }^{2,8}$

The age of the cattle being transported can have a great effect because morbidity and mortality increase in transported calves younger than three weeks of age, ${ }^{100}$ which may be confounded by the stress incurred by simultaneous weaning. ${ }^{82}$ Several differences have been found between calves of Bos indicus and Bos taurus during weaning and transportation, ${ }^{101}$ while it is generally agreed that cattle with genetically more excitable temperaments may remain agitated during handling procedures and transportation. ${ }^{7}$ Cattle that are habituated to the presence of humans and calves that are group-reared have lower plasma cortisol concentrations and lower heart rates following handling and transportation than extensively reared cattle or calves reared in isolation without contact with humans. ${ }^{64,82}$ Road conditions are another contributing factor, and higher heart rates have been observed in cattle transported on rough country roads or suburban roads with many stops and turns than those transported on highways. ${ }^{102}$ Most losses of balance during transportation that result in injury and bruising are driving-related and occur during cornering and braking, thereby adding the variable of the driver. ${ }^{60}$

In addition to the diseases associated with stress that were mentioned earlier, one of the most prevalent examples is "shipping fever" in transported cattle. The disease may have appeared as early as the late 1800 s to early 1900 s when cattle were first transported by railroad. ${ }^{103}$ The exact definition of shipping fever is not entirely agreed upon, nor its exact cause, although the simple description "the occurrence of pulmonary infections during or after transit" has been utilized. ${ }^{103}$ It is also recognized as being encompassed by the BRD complex, although the terms are often used interchangeably.

A series of scientific studies was conducted to evaluate the effects of transport by land and sea (roll-on, roll-off) journeys and of stocking density on the welfare of cattle 
transported within Ireland, from Ireland to Spain, and from Ireland to Italy under conditions outlined in Directive 91/628/EEC. Transport from Ireland to Spain, and from Ireland to Italy, had no adverse effect on animal welfare based on physiologic, hematologic, and immunologic measurements.

There was no welfare advantage in transporting bulls at a stocking density of $1.27 \mathrm{~m}^{2}$ versus the standard of $0.85 \mathrm{~m}^{2}$ on a 12-hour road journey (Table 4). Within the conditions of the transport studies, and based on the physiologic, hematologic, and immunologic measurements that were done to assess the welfare of control and transported animals, transport had no adverse effect on animal welfare. ${ }^{63}$

\section{Housing stress}

The welfare status of an animal depends on its ability to cope and exist in harmony with its environment, such that good physical and psychologic health is maintained. Improving animal welfare is an increasingly important aspect of livestock production systems and is due in large part to increased consumer concern about the source of animal products. Animal welfare has become an integrated part of quality assurance programs for sustainable animal production, considering that welfare, health, management, economy, consumer acceptance, and environmental impact are dependent on each other. The Organisation for Economic Cooperation and Development has acknowledged the fact that animal welfare is an emerging trade issue, and the international conventions already in place and ongoing work with

Table 4 Treatment means for plasma cortisol concentration and for IFN- $\gamma$ production by cultured lymphocytes following induction by either Con-A or KLH prior to transport and after a 12-hour journey ${ }^{63}$

\begin{tabular}{llll}
\hline & Treatment $^{2}$ & Pretransport & Posttransport \\
\hline Cortisol & Control & $7.48 \pm\left. 6.9\right|^{\mathrm{ax}}$ & $6.91 \pm 4.44^{\mathrm{a}}$ \\
$(\mathrm{ng} / \mathrm{mL})^{3}$ & TI27 & $8.17 \pm 5.22^{\mathrm{axy}}$ & $7.09 \pm 4.80^{\mathrm{a}}$ \\
& T085 & $9.15 \pm 4.64^{\mathrm{ay}}$ & $7.94 \pm 3.00^{\mathrm{a}}$ \\
Con-A IFN- $\gamma^{1,3}$ & Control & $0.278 \pm 0.20^{\mathrm{a}}$ & $0.224 \pm 0.179^{\mathrm{a}}$ \\
(absorbance at & TI27 & $0.230 \pm 0.216^{\mathrm{a}}$ & $0.189 \pm 0.158^{\mathrm{a}}$ \\
$450 \mathrm{~nm})$ & T085 & $0.197 \pm 0.169^{\mathrm{a}}$ & $0.181 \pm 0.190^{\mathrm{a}}$ \\
KLH IFN- $\gamma^{1,3}$ & Control & $0.026 \pm 0.046^{\mathrm{a}}$ & $0.029 \pm 0.047^{\mathrm{a}}$ \\
(absorbance at & TI27 & $0.024 \pm 0.037^{\mathrm{a}}$ & $0.009 \pm 0.035^{\mathrm{a}}$ \\
$450 \mathrm{~nm})$ & T085 & $0.021 \pm 0.03 \mathrm{I}^{\mathrm{a}}$ & $0.012 \pm 0.048^{\mathrm{a}}$ \\
\hline
\end{tabular}

Notes: 'Expressed as optical density measured at $450 \mathrm{~nm}$; ${ }^{2}$ Control, not transported; ${ }^{3}$ Values are expressed as mean \pm SD. TI 27 = transported for 12 hours at a stocking density of $1.27 \mathrm{~m}^{2}$ per animal; T085 = transported for 12 hours at a stocking density of $0.85 \mathrm{~m}^{2}$ per animal; ${ }^{\mathrm{a}, \mathrm{b}} \mathrm{Within}$ row means not having a common superscript differ significantly $(P \leq 0.00 \mathrm{I})$; ${ }^{x, y}$ Within column means not having a common superscript differ significantly $(P \leq 0.00 \mathrm{I})$.

Abbreviations: IFN- $\gamma$, interferon gamma; con-A, concavalin $A$; $K L H$, keyhole limpet hemocyanin; SD, standard deviation. the World Organization for Animal Health confirms this. Criteria for the assessment of farm animal housing have been proposed by several groups, and minimal standards for animal welfare are already implemented in the legislation of most European countries.

In Irish beef production systems, animals are generally housed in a concrete slatted-floored facility for a 4-5 month winter period at $2.2 \mathrm{~m}^{2} /$ head per $500 \mathrm{~kg}$ animal, ${ }^{104}$ and fed grass silage ad libitum with concentrate supplementation. High stocking densities of less than $2.0 \mathrm{~m}^{2} /$ head have been shown to affect adversely the frequency and duration of lying and levels of aggression within groups. Animal behavioral studies indicate that intensive stocking rates on slatted floors can present a significant challenge to the successful adaptation of cattle to confinement. High stocking densities have been shown to affect adversely the frequency and duration of lying behavior ${ }^{25,105-107}$ and levels of aggression within groups. High stocking densities can adversely affect production levels, ${ }^{25,26,107}$ with a positive response suggested to exist between daily gain and space allowance up to $4.7 \mathrm{~m}^{2} /$ head. $^{108-110}$

The effect of reduced space allowance $(1.5,2.0,2.5$, and $3.0 \mathrm{~m}^{2} /$ head) on the welfare of finishing heifers housed for a three-month period on slats was examined. ${ }^{25}$ Animals were fed silage ad libitum and $3 \mathrm{~kg}$ of concentrate DM, achieving a low daily live weight gain (mean $<0.70 \mathrm{~kg}$ /day). There was no effect of treatment on the measured immune response (serum IgG concentrations) to a mitogenic challenge. Neither was there any effect of treatment on the cortisol response of animals to an ACTH challenge at three different intervals during the study. However, because the critical welfare indicators (immune function, production, and behavior) may be influenced in a high production environment. When comparing deep-bedding accommodation with slatted floors for finishing cattle, short-term studies have concluded that animals have a greater preference for straw-bedded lying facilities than for slats. Long-term studies have shown that lying frequency can be affected by floor type. ${ }^{111,112}$ However, the conclusions of many long-term studies are confounded by space allowance (4.6 versus $2.2 \mathrm{~m}^{2} /$ head for straw and slats, respectively). ${ }^{108}$ In another study, the effects of space allowance and floor type on the welfare of beef cattle was examined. ${ }^{46}$ Friesian steers were blocked on body weight (mean $516 \mathrm{~kg}$ ) and randomly assigned to one of five groups $\left(1.5,2.0,3.0\right.$, or $4.0 \mathrm{~m}^{2} /$ head on slatted floors or $4.0 \mathrm{~m}^{2} /$ head on straw $[\mathrm{n}=15$ per treatment], Table 5). Over a three-month period, animals were offered concentrates ad libitum and $2 \mathrm{~kg}$ silage DM daily. Duration of time spent lying and eating 
Table 5 The effect of space allowance and floor type on animal performance ${ }^{46}$

\begin{tabular}{|c|c|c|c|c|c|c|}
\hline \multirow[t]{2}{*}{ Parameter } & \multicolumn{5}{|c|}{ Space allowance $\left(\mathrm{m}^{2} / \text { head }\right)^{\mathrm{w}}$} & \multirow[t]{2}{*}{ Significance } \\
\hline & 1.5 & 2 & 3 & 4 & 4 Straw & \\
\hline Average daily live weight gain (kg/day) & $0.60^{\mathrm{b}}$ & $0.80^{\mathrm{b}}$ & $1.10^{\mathrm{a}}$ & $1.10^{\mathrm{a}}$ & $1.10^{\mathrm{a}}$ & $* * *$ \\
\hline Final carcass weight $(\mathrm{kg})$ & $315.5^{d}$ & $323.0^{c}$ & $334.3^{b}$ & $341.6^{a}$ & $341.3^{\mathrm{a}}$ & $* * *$ \\
\hline Kill out & $0.552^{\mathrm{a}}$ & $0.549^{\mathrm{ab}}$ & $0.535^{b}$ & $0.54 I^{\mathrm{ab}}$ & $0.54 I^{\mathrm{ab}}$ & $*$ \\
\hline Initial carcass weight (kg) & 268.7 & 265.9 & 269.7 & 269.5 & 269.7 & ns \\
\hline Daily carcass gain (kg/day) & $0.48^{\mathrm{a}}$ & $0.59^{\mathrm{ab}}$ & $0.67^{b}$ & $0.74^{\mathrm{b}}$ & $0.74^{\mathrm{b}}$ & $* * *$ \\
\hline Conformation $^{x}$ & 1.9 & 1.8 & 2.0 & 2.1 & 2.1 & ns \\
\hline Fat score ${ }^{y}$ & 3.9 & 4.1 & 4.3 & 4.1 & 4.3 & ns \\
\hline Kidney/channel fat (g/kg carcass) & $40.8^{c}$ & $43.1^{\mathrm{b}}$ & $47.3^{\mathrm{a}}$ & $43.0^{b}$ & $46.8^{\mathrm{a}}$ & $*$ \\
\hline Feed conversion efficiency ${ }^{z}$ & $20.6^{\mathrm{b}}$ & $19.0^{\mathrm{b}}$ & $18.2^{\mathrm{ab}}$ & $16.0^{\mathrm{a}}$ & $15.9^{a}$ & $*$ \\
\hline
\end{tabular}


efficiency $=$ kg DM intake/kg carcass gain.

and the frequency of social and stereotypic behaviors were recorded. Hematologic and biochemical (nonesterified fatty acids, creatine kinase, $\beta$-hydroxybutyrate, haptoglobin, and fibrinogen) measurements were made. The immune status of all animals was assessed by immunizing against KLH and assessing in vitro IFN- $\gamma$ production. There was no effect of space allowance on time spent eating. Lying time was affected by treatment $(P<0.05)$. Time spent lying on slats was decreased at $<2 \mathrm{~m}^{2} /$ head $(P<0.05)$, while animals lay longer on straw beds $(P<0.05)$. The frequency of social interactions increased with space allowance $(P<0.001)$, while aggressive interactions were greatest at the lowest and highest space allowances $(P<0.01)$. The provision of a straw bed increased the frequency of grooming behaviors $(P<0.05)$. There was no effect of space allowance on blood cell counts, blood metabolites, haptoglobin, or fibrinogen. There was a significant effect of space allowance on dirt score. Increased space allowance increased carcass gain $(P<0.001)$ and decreased feed conversion ratio $(\mathrm{kg}$ $\mathrm{DM}$ intake/kg carcass gain, $P<0.05)$. In vitro IFN- $\gamma$ was compromised when animals were housed at $<2 \mathrm{~m}^{2} /$ head $(P<0.05)$. There was no effect of floor type on carcass gain, feed conversion efficiency, or IFN- $\gamma$ response. The authors concluded that space allowance $<3 \mathrm{~m}^{2}$ /animal, but not floor type, adversely influenced animal welfare.

Provision of adequate space allowances during the housing period for cattle determines their welfare status and also enables control over labor costs. ${ }^{113}$ Housing protects animals from adverse weather conditions and provides structured management (feeding, drinking, health checking,) under controlled conditions. However, insufficient space allowance induces prolonged stress by preventing animals from performing their natural behavior, altering HPA axis secretion, immune function, and performance. ${ }^{47,108,113}$ Therefore, inadequate space allowance is viewed as a potential welfare concern for cattle kept under confined conditions.

Several studies have been conducted on the effect of varied (greater versus lesser) space allowances on the behavioral activities of cattle, with conflicting results. No change in lying behavior was noted in bulls housed at $2 \mathrm{~m}^{2}$ versus $3 \mathrm{~m}^{2}$ average individual space allowance. ${ }^{114}$ While Dome ${ }^{115}$ reported a tendency for a reduction in lying behavior in bulls (housed at $1.95 \mathrm{~m}^{2}$ compared with $\left.2.60 \mathrm{~m}^{2}\right),{ }^{115}$ others demonstrated reduced lying time and reduced number of eating bouts in cattle with reduced space allowances $\left(1.5 \mathrm{~m}^{2}\right.$ and $2.0 \mathrm{~m}^{2}$ space allowance ${ }^{26}$ and $2.3 \mathrm{~m}^{2}$ and $2.7 \mathrm{~m}^{2}$ space allowance ${ }^{116,117}$ ), respectively. Increased levels of aggressive behavior was reported in cattle housed at $1.95 \mathrm{~m}^{2}$ versus $2.60 \mathrm{~m}^{2}$ space allowance, ${ }^{115}$ while other authors reported interruption in expressing natural behavior in cattle housed in pens with slatted flooring and low space allowances. ${ }^{118,119}$ and reduced lying time when cattle were housed at a space allowance of $1.5 \mathrm{~m}^{2}$ compared with $3.0 \mathrm{~m}^{2}$ per animal. ${ }^{47}$

As space allowance for young bulls on slatted floors was increased, the level of aggression ${ }^{120}$ and abnormal behavior ${ }^{115}$ was decreased. Others reported that increasing the resting area from 1.8 to 2.7 or $2.65 \mathrm{~m}^{2}$ per animal improved the welfare of group-housed cattle. ${ }^{121}$ While some authors ${ }^{26,47}$ found no effect on lying time at $2 \mathrm{~m}^{2}$ per animal or greater $\left(3 \mathrm{~m}^{2}\right)$ others found that fattening bulls spent a greater percentage of their time lying at $4 \mathrm{~m}^{2}$ than at $2 \mathrm{~m}^{2}$ per animal. ${ }^{107}$ From these findings it is concluded that cattle housed in groups require more than the individual lying area suggested by a nallometric equation, ${ }^{122}$ which defines a minimal space of $1.5 \mathrm{~m}^{2}$ required by an animal when lying. Under conditions of excessively large groups ( $>100$ animals) with minimum space allowances, ${ }^{120,123}$ individual animals appear to have difficulty in memorizing the social status of all peers, which 
increases the incidences of social aggressiveness and stereotypies in cattle. ${ }^{115,124,125}$ Bulls housed with reduced space allowance were found to spend several minutes in every hour showing tongue-rolling behavior that indicates increased aggression, probably associated with reduced feeding space or when animals cannot eat at the same time. ${ }^{126}$ It was also observed that reduced trough length in slatted-floor housing increased the frequency and decreased the duration of feeding periods. ${ }^{119}$ In contrast, when others ${ }^{26}$ compared $1.5 \mathrm{~m}^{2}$ and 3.0 $\mathrm{m}^{2}$ space allowances for housed cattle on slatted floors, the restricted space allowances reduced the incidence of nonaggressive social interaction and increased leaning behavior (head resting either on an inanimate object or upon other animals). Similar observations were reported in another housing study which showed no effect of space allowances (1.5, 2.0 , and $4.0 \mathrm{~m}^{2}$ ) on social interaction, stereotypic behaviors, grooming, or aggressive interactions of housed cattle. ${ }^{47}$

There are limited studies to evaluate the effect of space allowances on the immunologic parameters of cattle. While one study ${ }^{47}$ reported the attenuation of lymphocyte proliferation in ex vivo immune function tests for cattle at less than $2 \mathrm{~m}^{2}$ space allowances, another study found no differences for ex vivo cellular functions between 1.5, 2.0, 2.5, and $3 \mathrm{~m}^{2}$ per heifer space allowances. ${ }^{25}$ In the latter study, there were no effects of space allowance on anti-KLH IgG1 or IgG2 antibody responses. Mean preimmunization anti-KLH IgG1 and $\mathrm{IgG} 2$ were less than 0.03 and 0.06 absorbance units, respectively. ${ }^{25}$ No effects on white blood cells, red blood cells, hematocrit percentage, and hemoglobin from day 0 to day 96 in heifers housed at $1.5 \mathrm{~m}^{2}$ or $3.0 \mathrm{~m}^{2}$ average individual space allowance ${ }^{25}$ and steers housed at 1.5, 2.0, 3.0, or $4.0 \mathrm{~m}^{2}$ each $^{47}$ have been reported. In an experiment with water buffalo calves, it was reported that the in vivo cellmediated immune response to phytohemagglutin-A (PHA) injection was influenced by space allowance. ${ }^{127}$ The authors reported that a higher spatial density $\left(1.5\right.$ and $1.0 \mathrm{~m}^{2} /$ calf versus $2.6 \mathrm{~m}^{2} /$ calf) reduced hypersensitivity to PHA, indicating that space restriction has detrimental effects on cellular immune responses.

\section{Implications for biomedical models}

Studies have examined phenotypic alterations of blood leukocytes as potential biologic indicators of physiologic stress and disease susceptibility in humans and animals. However, most of the indicators tested have been used with little biologic justification. Rather, indicators such as the ratio of CD4:CD8 lymphocytes or the NL ratio in blood have been used in such studies because researchers have the equipment to perform these measurements and can show impressive changes in these parameters due to imposed stressors. ${ }^{128-131}$ In cattle, for example, clear changes in circulating numbers of neutrophils and lymphocytes, attenuated proliferation of T- and B-lymphocytes, and modified expression of surface adhesion and antigen-presenting molecules on leukocytes subjected to stress hormones in vivo and in vitro have been documented. ${ }^{4,68,132}$ While these measurements may indicate that something is going on in the test animals, they are in no way diagnostic of what the overall physiologic response is. Lack of availability of appropriate stress diagnostics is due to a lack of basic knowledge about what stress and stress hormones do to blood leukocytes at the molecular level.

Because interactions between stress hormones and leukocytes are highly complex, influenced by the animal, ${ }^{133}$ leukocyte type, ${ }^{128}$ leukocyte activation status, and presence of concurrent metabolic and infectious disease, ${ }^{134}$ in addition to the blood hormonal milieu, simple functional assays alone will never elucidate or explain the full response of the cells to stress. To enable reliable and precise diagnosis and treatment of stress in the future will require that we move beyond the isolated study of gross cellular responses to stress and begin to identify the molecular mechanisms associated with these responses.

Increasingly, microarray technology and next-generation sequencing technology are being used to overview the genomic response of cells to specific experimental and/or biologic conditions. More recently, the expression changes of candidate neutrophil genes known to be altered in other stress models as well as novel genes on a transcriptome-wide scale by cDNA microarray analysis in relation to transportation of young cattle were investigated..$^{70,72}$ The genes selected for profiling were sensitive to glucocorticoids in other stress models and included Fas, A1, matrix metalloproteinase-9 (MMP-9), L-selectin, bactericidal/permeability-increasing protein (BPI), transforming growth factor- $\beta$ receptor Type III (subsequently referred to as betaglycan), and glucocorticoid receptor- $\alpha$. Eighty-eight genes were found to be differentially expressed $(P<0.05)$ between -24 and $4.5,9.75$, or 14.25 hours relative to transport, when cortisol and neutrophilia were at their peaks. These 88 genes were grouped into ontological clusters based on their relevance to respiratory tract defense and potential roles in the "neutrophil paradox": signal transduction $(n=16)$, immune response $(15)$, unknown (14), protein trafficking (7), apoptosis (6), transcriptional regulation (6), ribosomal (6), wound healing (5), mitochondrial (3), metabolic enzymes (2), translational regulation (2), ubiquitin pathways (2), protein activation (1), RNA 
processing (1), steroid (1), and cell structure (1). Thirty-one genes involved in the immune response, apoptosis, wound healing, and unknown clusters were selected for independent validation by quantitative real-time polymerase chain reaction (qRT-PCR); the expression changes for 14 of these genes were validated or tended towards validation $(P<0.10)$. Proapoptotic caspase 13 and tumor necrosis factor receptorassociated factor 6 (TRAF6) were downregulated by transport stress $(P<0.01)$, while expression of death-associated protein kinase was not confirmed as changed $(P=0.80)$. The antiapoptotic bcl-2 family member mcl-1 tended to decrease at 14.25 hours $(P=0.06)$. Expression of the neutrophil chemoattractant Gro- $\gamma$ increased numerically but was not significant $(P=0.21)$. Antifibrotic and anti-inflammatory betaglycan was profoundly downregulated during transport stress $(P<0.05)$. In fact, the altered regulation of many genes may suggest a reprogramming of neutrophils with a greater potential for antibacterial capacity and potential tissue injury. Differentially expressed genes fell in three major functional groups that would support this, ie, immune function, apoptosis, and wound healing. The candidate genes identified as differentially expressed by transportation, ie, L-selectin and BPI (immune function), Fas (apoptosis), and MMP-9 (wound healing), could easily fall into these same groups. A general upregulation in genes responsible for the regulation of chemotaxis, activation, migration, and antibacterial capacity in immune function was observed (L-selectin, BPI, IL-8, eotaxin-2-like protein, ICAM-3, semaphorin 4A, and erythropoietin). Apoptosis genes (Fas, p21, and caspase 13) were regulated so as to suggest a delay in apoptosis and prolonged neutrophil survival. The expression of wound healing genes (MMP-9, peroxisome proliferator-activated receptor gamma, and platelet-derived growth factor alpha) were altered in a way that would propose an increase in tissue remodeling and wound healing functions which may lead to excessive degradation or excessive fibrous deposition.

Neutrophils, as well as many other immune cells, are well-known targets of stress hormones, possessing receptors for catecholamines and glucocorticoids secreted during an acute stress response. Bovine neutrophils have been shown to exhibit differential expression of genes which have important roles in immune function, apoptosis, tissue remodeling, and various metabolic and cellular functions in response to glucocorticoids in vitro and in vivo. Although many reports have investigated neutrophil function during natural and experimental cases of BRD, none have investigated the effects of weaning alone or in combination with transportation on neutrophil gene expression, let alone on a transcriptome- wide scale. Tools developed in the past decade in the fields of functional genomics and proteomics have allowed for the identification of thousands of molecular changes at once in physiologic or disease states. Use of these tools may discover potential targets for therapeutics and genetic selection, and may present a pattern of genomic or proteomic changes as biomarkers of a disease. The ability to treat BRD especially in multiple-sourced and comingled transported animals is becoming more difficult. With the emergence of antibioticresistant pneumonia in feedlot cattle, more targeted and selective use of antimicrobials in the animal industry is sought. It has long been observed that an association exists between stress and disease susceptibility, namely BRD, in domestic farm animals, although a definitive causal factor has yet to be defined. Many researchers have implicated a suppression of the host's immune system by stress that allows opportunistic infectious pathogens to invade. Furthermore, substantial evidence has suggested that this immunosuppression is mediated by glucocorticoids following activation of the HPA axis by a stressor. However, recent research has suggested that stress, and its association with increased glucocorticoid concentrations, is not solely immunosuppressive and may actually enhance immune function. ${ }^{135}$ In either case, susceptibility to disease may increase because neither inadequate nor excessive activation of immune components is ideal in the prevention of disease.

\section{Conclusion}

The living environment is not benign and exposes animals to various threats from normal physiologic processes such as parturition, or externally from pathogens, stress, transport, social interactions, or interference for health reasons. They are also of fundamental economic importance to the economy. Advances in molecular biology will become driving forces in the development of innovative technologies that will help underpin economic development and prosperity in the next two to three decades. Gaining an insight into the genes that regulate the basic biology of the stress-immune axis will provide a unique understanding of its fundamental mechanism of action at the molecular level. The unlocking of these molecular mechanisms will help lead to the discovery of key genes and proteins that can be exploited in the future to boost the immune system and modulate the environment of the animal in order to improve the health and well being of both animals and humans. The recent major advance of understanding functional genomes through the development of DNA microarray technology and next-generation sequencing allows scientists to investigate the gene expression profiles 
of thousands of genes simultaneously and over critical physiologic time periods. Gene expression patterns can be measured in control and challenged animals (poor stress/welfare and reduced immunocompetency) and the array of genes that are up- or downregulated can be discovered for the first time. This knowledge will help lead to the discovery of new ways to control or boost the stress-immune axis in cattle.

\section{Disclosure}

The authors report no conflicts of interest in this work.

\section{References}

1. Griffin JFT. Stress and immunity: A unifying concept. Vet Immunol Immunopathol. 1989;20:263-312.

2. Sorrells SF, Sapolsky RM. An inflammatory review of glucocorticoid actions in the CNS. Brain Behav Immun. 2007;21:259-272.

3. Blecha F, Boyles SL, Riley JG. Shipping suppresses lymphocyte blastogenic responses in Angus and Brahman, Angus feeder calves. J Anim Sci. 1984;59:576-583.

4. Burton JL, Madsen SA, Chang LC, et al. Gene expression signatures in neutrophils exposed to glucocorticoids: A new paradigm to help explain "neutrophil dysfunction" in parturient dairy cows. Vet Immunol Immunopathol. 2005;105:197-219.

5. Dantzer R, Mormède P. Stress in farm animals: A need for reevaluation. J Anim Sci. 1983;57:6-18.

6. Grandin T. Review: Reducing handling stress improves both productivity and welfare. Prof Anim Sci. 1998;14:1-10.

7. Grandin T. Assessment of stress during handling and transport. JAnim Sci. 1997;75:249-257.

8. Minton JE. Function of the hypothalamus-pituitary-adrenal axis and the sympathetic nervous system in models of acute stress in domestic farm animals. J Anim Sci. 1994;72:1891-1898.

9. Kehrli ME Jr, Burton JL, Nonnecke BJ, et al. Effects of stress on leukocyte trafficking and immune responses: Implications for vaccination. In: Schultz RD, editor. Advances in Veterinary Medicine Veterinary Vaccine and Diagnostics. Volume 41. New York, NY: Academic Press; 1999.

10. Oireachtas. Protection of Animals (Amendment) Act 1965. The Irish Statute Book online database. Available from: http://www. irishstatutebook.ie/1965/en/act/pub/0010/index.html. Accessed 2010 March 31.

11. Department for the Environment, Food and Rural Affairs. Code of Recommendations for the Welfare of Livestock: Cattle. London, UK: DEFRA Publications; Department for the Environment, Food and Rural Affairs. 2003. Available from: http://www.defra.gov.uk/ animalh/welfare/farmed/cattle/booklets/cattcode.pdf. Accessed 2010 March 31.

12. Stafford KJ, Mellor DJ, McMeekan CM. A survey of the methods used by farmers to castrate calves in New Zealand. $N Z$ Vet $J$. 2000;48:16-19.

13. Steiner A, Bettschart R, Schatzmann U. Kastration von männlichen Lämmern und Kälbern: Erläuterungen und Kommentare zu Art. 65 TSchV. Arch Tierheilkd. 2002;144:107-113. German.

14. Capucille DJ, Poore MH, Rogers GM. Castration in cattle: Techniques and animal welfare issues. Compend Contin Educ Pract Vet. 2002;24:S66-S73.

15. Appleby MC. Development of sexual and agonistic behavior in bulls and steers. Appl Anim Behav Sci. 1986;15:190.

16. Mullen PA. Some observations on the effects of the method and time of castration of calves for barley beef production. Brit Vet $J$. 1964;120:518-523.

17. Fenton BK, Elliot J, Campbell RC. The effects of different castration methods on the growth and well-being of calves. Vet Rec. 1958;70:101-102.
18. Molony V, Kent JE, Robertson IS. Assessment of acute and chronic pain after different methods of castration of calves. Appl Anim Behav Sci. 1995;46:33-48.

19. Mellor DJ. Effects of castration on behavior and plasma cortisol concentrations in young lambs, kids and calves. Res Vet Sci. 1991;1149-1151.

20. Earley B, Crowe MA. Effects of ketoprofen alone or in combination with local anesthesia during castration of bull calves on plasma haptoglobin, in vitro interferon-G production, white blood cell numbers and animal performance. J Anim Sci. 2002;80:1044-1052.

21. Fell LR, Wells R, Shutt DA. Stress in calves castrated surgically or by the application of rubber rings. Aus Vet J. 1986;63:16-18.

22. Kehlet H. Neurohumoral response to surgery and pain in man. In: Bond MR, Charlton JE, Woolf CJ, editors. Proceedings of the VIth World Congress on Pain. Amsterdam, The Netherlands: Elsevier Science Publishers; 1991.

23. Kent JE. Thrusfield MV, Robertson IS, Molony V. Castration of calves: A study of methods used by farmers in the United Kingdom. Vet Rec. 1996;138:384-387.

24. Fisher AD, Crowe MA, Alonso de la Varga ME, Enright WJ. Effect of castration method and the provision of local anaesthesia on plasma cortisol, scrotal circumference, growth and feed intake of bull calves. J Anim Sci. 1996;74:2336-2343.

25. Fisher AD, Crowe MA, O'Kiely P, Enright WJ. Growth, behavior, adrenal and immune responses of finishing beef heifers housed on slatted floors at 1.5, 2.0, 2.5 or $3.0 \mathrm{~m}^{2}$ space allowance. Live Prod Sci. 1997;51:245-254.

26. Fisher AD, Crowe MA, O'Nuallain EM, et al. Effects of suppressing cortisol following castration of bull calves on adrenocorticotropic hormone, in vitro interferon-gamma production, leukocytes, acute phase proteins, growth and feed intake. J Anim Sci. 1997; 75:1899-1908.

27. Chase CC Jr, Larsen RE, Randel RD, Hammond AC, Adams LE. Plasma cortisol and white blood cell responses in different breeds of bulls: A comparison of two methods of castration. J Anim Sci. 1995;73:975-980.

28. Robertson IS, Kent JE, Moony V. Effect of different methods of castration on behavior and plasma cortisol in calves of three ages. Res Vet Sci. 1994;56:8-17.

29. Jennings PB. Testicular surgery. In: The Practice of Large Animal Surgery. Volume II. Philadelphia, PA: WB Saunders; 1984.

30. Pang WP, Earley B, Sweeney T, Crowe MA. Effect of carprofen administration during banding or burdizzo castration of bulls on plasma cortisol, in vitro interferon concentrations in calves. Vet $J$. 2006;168:297-303.

31. Pang WY, Earley B, Gath V, Crowe MA. Effect of banding or burdizzo castration on plasma testosterone, acute-phase proteins, scrotal circumference, growth, and health of bulls. Livestock Science. 2007;117(1):79-87.

32. Ting STL, Earley B, Crowe MA. Effect of repeated ketoprofen administration during surgical castration of bulls on cortisol, immunological function, feed intake, growth, and behavior. J Anim Sci. 2003;81:1253-1264.

33. Ting STL, Earley B, Hughes JM, Crowe MA. Effect of ketoprofen, lidocaine local anesthesia, and combined xylazine and lidocaine caudal epidural anesthesia during castration of beef cattle on stress responses, immunity, growth and behavior. J Anim Sci. 2003;81:1281-1293.

34. Ting STL, Earley B, Crowe MA. Effect of cortisol infusion pattterns and castration on metabolic and immunological indices of stress response in cattle. Dom Anim Endocrinol. 2004;26:329-349.

35. Ting STL, Earley B, Veissier I, Gupta S, Crowe MA. Effects of age of Holstein-Friesian calves on plasma cortisol, acute-phase proteins, immunological function, scrotal measurements and growth in response to Burdizzo castration. Anim Sci. 2005;80:377-386.

36. Keane MG. Effects of time of complete or split castration on performance of beef cattle. Irish J Agr Food Res.1999;38:41-51. 
37. Von Keyserlingk MAG, Weary DM. Maternal behavior in cattle. Horm Behav. 2007;52:106-113.

38. Veissier I, Le Neindre P, Trillat G. Adaptability of calves during weaning. Biol Behav. 1989;14:66-87.

39. Veissier I, Le Neindre P. Weaning in calves: Its effect on social organisation. Appl Anim Behav Sci. 1989;24:43-54.

40. von Borell EH. The biology of stress and its application to livestock housing and transportation assessment. J Anim Sci. 2001; 79:E260-E267.

41. Veissier I, Le Neindre P, Garel JP. Decrease in cow-calf attachment after weaning. Behav Proc. 1990;21:95-195.

42. Phillips WA, Juniewicz PE, Zavy MT, Von Tungel DL. The effect of the stress of weaning and transport on white blood cell patterns and fibrinogen concentration of beef calves of different genotypes. Can J Anim Sci. 1989;69;333-340.

43. Church JS, Hudson RJ. Comparison of the stress of abrupt and interval weaning of farmed wapiti calves (Cervus elaphus). Small Rum Res. 1999;32:119-124.

44. Sevi A, Taibi L, Albenzio M, Muscio A, Dell Aquila S, Napolitano F. Behavioral, adrenal, immune and productive responses of lactating ewes to regrouping and relocation. J Anim Sci. 2001;79: 642-652.

45. Mackenzie AM, Drennan M, Rowan TG, Dixon JB, Carter SD. Effect of transportation and weaning on humoral immune responses of calves. Res Vet Sci. 1997;63:227-230.

46. Hickey MC, Earley B, Fisher AD. The effect of floor type and space allowance on welfare indicators of finishing steers. Irish J Agr Food Res. 2003;42:89-100.

47. Hickey MC, Drennan M, Earley B. The effect of abrupt weaning of suckler calves on the plasma concentrations of cortisol, catecholamines, leukocytes, acute phase proteins and in vitro interferongamma production. J Anim Sci. 2003;81:2847-2855.

48. Pollock JM, Rowan TG, Dixon JB, Carter SD, Kelly DF. Estimation of immunity in the developing calf: Cellular and humoral responses to keyhole limpet haemocyanin. Vet Immunol Immunopathol. 1999;29:105-113.

49. Toates F. Neuronal and hormonal control. In: Toates F, editor. Stress: Conceptual and Biological Aspects. West Sussex, UK: Wiley and Sons Ltd; 1995.

50. Agnes F, Sartorelli P, Abdi BH, Locatelli A. Effect of transport loading or noise on blood biochemical variables in calves. Am J Vet Res. 1990;51:1679-1681.

51. Guyton AC. Textbook of Medical Physiology. 8th ed. Philadelphia, PA: WB Saunders; 1991.

52. Wood PR, Seow, HF. T cell cytokines and disease prevention. Vet Immunol Immunopathol. 1996;54:33-44.

53. Harris JR, Markl J. Keyhole limpet haemocyanin (KLH): A biomedical review. Micron. 1999;30:597-623.

54. Lefcourt AM, Bitman J, Kahl S, Wood DL. Circadian and ultradian rhythms of peripheral cortisol concentration in lactating dairy cows. J Dairy Sci. 1993;76:1757-1762.

55. Anderson BB, Watson DL, Colditz IG. The effect of dexamethasone on some immunological parameters in cattle. Vet Commun. 1999;23:399-413.

56. Minton JE, Coppinger TR, Reddy PG, Davis WC, Blecha F. Repeated restraint and isolation stress alters adrenal and lymphocyte functions and some leukocyte differentiation antigens in lambs. J Anim Sci. 1992;70:1126-1135.

57. Qui Y, Peng Y, Wang J. Immunoregulatory role of neurotransimitters. Adv Neuroimmunol. 1996;6:223-231.

58. Ansted-Michael I, Hunt A, Carlson L, Burli K. Variability of peripheral blood lymphocyte beta-2-adrenergic receptor density in humans. Amer J Respir Crit Care Med. 1988;157:990-992.

59. Veissier I, Lamy D, Le Neindre P. Social behavior in domestic beef cattle when yearling calves are left with the cows for the next calving. Appl Anim Behav Sci. 1990;27:193-200.
60. Kenny FJ, Tarrant PV. The behavior of young Friesian bulls during social re-grouping at an abbatoir. Influence of an overhead electrified wire grid. Appl Anim Behav Sci. 1987;18:233-246.

61. Kenny FJ, Tarrant, PV. The physiological and behavioral responses of crossbred fresian steers to short-haul transport by road. Livest Prod Sci. 1987; 17:63-75.

62. Earley B, Fisher AD, O'Riordan EG. Effects of pre-transport fasting on the physiological responses of young cattle to 8 -hour road transport. Irish J Agr Food Res. 2006;45:51-60.

63. Earley B, O'Riordan EG. Effects on transporting bulls at different space allowances on physiological, haematological and immunological responses to a 12-h journey by road. Irish J Agr Food Res. 2006;45:39-50.

64. Tarrant PV. Transportation of cattle by road. Appl Anim Behav Sci. 1990;28:153-170.

65. Tennessen T, Price MA, Berg RT. Comparative responses of bulls and steers to transportation. Can J Anim Sci. 1984;64:333-338.

66. Todd SE, Mellor DJ, Stafford KJ, Gregory NG, Bruce RA, Ward RN. Effects of food withdrawal and transport on 5-to 10-day-old calves. Res Vet Sci. 2000;68:125-134.

67. Blecha F, Baker PE. Effect of cortisol in vitro and in vivo on production of bovine interleukin 2. Am J Vet Res. 1986;47:841-845.

68. Murata $\mathrm{H}$, Takahashi $\mathrm{H}$, Matsumoto $\mathrm{H}$. The effects of road transportation on peripheral blood lymphocyte subpopulations, lymphocyte blastogenesis and neutrophil function in calves. Br Vet $J$. 1987;143:166-174.

69. Swanson JC, Morrow-Tesch J. Cattle transport: Historical, research, and future perspectives. JAnim Sci. 2001; Suppl 79: E102-E109.

70. Buckham Sporer KR, Burton JL, Earley B, Crowe MA. Transportation stress in young bulls alters expression of neutrophil genes important for the regulation of apoptosis, tissue remodeling, margination, and antibacterial function. Vet Immunol Immunopathol. 2007;118:19-29.

71. Buckham Sporer KR, Burton JL, Earley B, Crowe MA. Transportation of young beef bulls alters circulating physiological parameters that may be effective biomarkers of stress. J Anim Sci. 2008;86:1325-1334.

72. Sporer KR, Xiao L, Tempelman RJ, Burton JL, Earley B, Crowe MA. Transportation stress alters the circulating steroid environment and neutrophil gene expression in beef bulls. Vet Immunol Immunopathol. 2008;121:300-320.

73. Gupta S, Earley B, Crowe MA. Effect of 12-hour road transportation on physiological, immunological and haematological parameters in bulls housed at different space allowances. Vet J. 2007;173:605-616.

74. Knowles TG. A review of the road transport of cattle. Vet Rec. 1999;144:197-201.

75. Tarrant PV, Kenny FJ, Harrington D, et al. Long distance transportation of steers to slaughter: Effect of stocking density on physiology, behavior, and carcass quality. Livest Prod Sci. 1992;30:223-238.

76. SCAHAW. The welfare of cattle kept for beef production. Publication of the European Commission, Health and Consumer Protection Directorate-General by the Scientific Committee on Animal Health and Animal Welfare (SCAHAW) SANCO.C.2/AH/R22/2000. Adopted 2001 April 25. Available at: http://ec.europa.eu/food/fs/sc/scah/ out54_en.pdf. Accessed on 2010 March 31.

77. Warriss PD, Brown SN, Knowles TG, et al. Effects on cattle of transport by road for up to 15 hours. Vet Rec. 1995;136:319-323.

78. Eicher SD. Transportation of cattle in the dairy industry: Current research and future directions. J Dairy Sci. 2001; Suppl 84:E19-E23.

79. Marahrens M, Von Richthofen I, Schmeiduch S, Hartung J. Special problems of long-distance road transports of cattle. Deut Tier Woch. 2003;110:120-125.

80. Grigor PN, Cockram MS, Steele WB, et al. Effects of space allowance during transport and duration of mid-journey lairage period on the physiological, behavioral and immunological responses of young calves during and after transport. J Anim Sci. 2001;73: $341-360$.

81. Knowles TG, Warriss PD, Brown SN, Edwards JE. Effects on cattle of transportation by road for up to 31 hours. Vet Rec. 1999;145:575-582. 
82. Tracey DJ, Walker JS. Pain due to nerve damage: Are inflammatory mediators involved. Inflamm Res.1995;44:407-411.

83. Arthington JD, Eicher SD, Kunkle WE, Martin FG. Effect of transportation and commingling on the acute-phase protein response, growth, and feed intake of newly weaned beef calves. J Anim Sci. 2003;81:1120-1125.

84. Crookshank HR, Elissalde MH, White RG, Clanton DC, Smalley HE. Effect of transportation and handling of calves upon blood serum composition. J Anim Sci. 1979;48:430-435.

85. Gupta S, Earley B, Crowe MA. Pituitary, adrenal, immune and performance responses of mature Holstein $\times$ Friesian bulls housed on slatted floors at various space allowances. Vet J. 2007;173:594-604.

86. Kent JE, Ewbank R. The effect of road transportation on the blood constituents and behavior of calves. I. Six months old. Br Vet J. 1983;139:228-235.

87. Yagi Y, Shiono H, Chikayama Y, Ohnuma A, Nakamura I, Yayou K. Transport stress increases somatic cell counts in milk, and enhances the migration capacity of peripheral blood neutrophils of dairy cows. J Vet Med Sci. 2004;66:381-387.

88. Odore R, D'Angelo A, Badino P, Bellino C, Pagliasso S, Re G. Road transportation affects blood hormone levels and lymphocyte glucocorticoid and $\widetilde{\beta}$-adrenergic receptor concentrations in calves. Vet $J$. 2004; 168:297-303.

89. Higuchi H, Katoh N, Miyamoto T, Uchida E, Yuasa A, Takahashi K. Dexamethasone-induced haptoglobin release by calf liver parenchymal cells. Am J Vet Res.1994;55:1080-1085.

90. Mitchell G, Hattingh J, Ganhao M. Stress in cattle assessed after handling, after transport and after slaughter. Vet Rec. 1988;123:201-205.

91. Campbell NA, Reece JB, Mitchell LG. In: Mulligan E, editor. Biology. Menlo Park, CA: Benjamin/Cummings; 1999.

92. Ishizaki H, Hanafusa Y, Kariya Y. Influence of truck-transportation on the function of bronchoalveolar lavage fluid cells in cattle. Vet Immunol Immunopathol. 2004;105:67-74.

93. Dixit VD, Marahrens M, Parvizi N. Transport stress modulates adrenocorticotropin secretion from peripheral bovine lymphocytes. J Anim Sci. 2001;79:729-734.

94. Riondato F, D'Angelo A, Miniscalco B, et al. Effects of road transportation on lymphocyte subsets in calves. Vet J. 2008;175:364-368.

95. Baumann H, Gauldie J. The acute phase response. Immunol Today. 1994;15:74-80

96. Horadagoda NU, Knox KM, Gibbs HA, et al. 1999. Acute phase proteins in cattle: Discrimination between acute and chronic inflammation. Vet Rec. 1999;144:437-441.

97. Murata H, Miyamoto T. Bovine haptoglobin as a possible immunomodulator in the sera of transported calves. Br Vet J. 1993;149:277-283.

98. Miller JK, Brzezinska-Slebodzinska E. Oxidative stress, antioxidants, and animal function. J Dairy Sci. 1993;76:2812-2823.

99. Chirase NK, Greene LW, Purdy CW, et al. Effect of transport stress on respiratory disease, serum antioxidant status, and serum concentrations of lipid peroxidation biomarkers in beef cattle. Am J Vet Res. 2004;65:860-864.

100. Staples GE, Haugse CN. Losses in young calves after transportation. Br Vet J. 1974;130:374-378.

101. Phillips WA, Juniewicz PE, Zavy MT, Von Tungeln DL. The effects of the stress of weaning and transit on performance and metabolic profile of beef calves of different genotypes. Can J Anim Sci. 1987;67:991-999.

102. Eldridge GA, Winfield CG, Cahill DJ. Responses of cattle to different space allowances, pen sizes and road conditions during transport. Aust J Exp Agr. 1998;28:155-159.

103. Yates WDG. A review of infectious bovine rhinotracheitis, shipping fever, pneumonia and viral-bacterial synergism in respiratory disease in cattle. Can J Comp Med. 1983;46:225-263.

104. Dodd VA. Housing for a beef unit. Vet Update. 1988;6.

105. Andreae U, Smidt D. Behavioral alterations in young cattle on slatted floors. In: Bessei W, editor. Disturbed Behavior in Farm Animals. Stuttgart; Eugen Ulmer; 1982.
106. Maton A, Daelemans J. Modern housing of cattle and their welfare. In: Dodd VA, Grace PM, editors. Agricultural Engineering Volume 2, Proceedings of the 11th International Congress on Agricultural Engineering. Dublin, Ireland. 1989 September 4-8. Rotterdam: AA Balkema; 1989:921-925.

107. Ruis-Heutinck LFM, Smits MCJ, Smits AC, Heeres JJ. Effects of floor type and floor area on the behavior and carpal joint lesions in beef bulls. Proceedings of sessions of the EAAP Commission on Animal Management and Health. The Hague, Netherlands, August 21-24. EEAP Publication Number 2; 2000;102:29-36.

108. Ingarvarsten KL, Andersen HR. Space allowance and type of housing for growing cattle. Acta Agric Scand. 1993;43:65-80.

109. Bateman A, Singh A, Kral T, Soloman S. The immune-hypothalmicpituitary-adrenal axis. Endocr Rev.1989;10:92-107.

110. Roth JA. Cortisol as a mediator of stress-associated immunosuppression in cattle. In: Moberg GP, editor. Animal Stress. Baltimore, MD: Waverly Press Inc.; 1985.

111. Lowe DE, Steen RWJ, Beattie VE, Moss BW. The effects of floor type systems on the performance, cleanliness, carcass composition and meat quality of housed finishing beef cattle. Livest Prod Sci. 2001;69:33-42.

112. Lowe DE, Steen RWJ, Beattie VE. Preference testing of floor type by finishing cattle. Proceedings of Irish Grassland and Animal Production Association. 26th Meeting, University College Dublin, Ireland. 14 Mar 2000. Research Forum UCD: 2000;185-186.

113. Jóhannesson T, Sørensen JT. Evaluation of welfare indicators for the social environment in cattle herds. Anim Welfare. 2000;9:297-316.

114. Andreae U, Unshelm J, Smidt D. Behavior and physiological adaptation reactions of growing bulls at various housing densities on slatted floor loose boxes. Tierzuchter.1989;32:467-468.

115. Wierenga HK, Peterse DJ. Cattle housing systems, lameness and behavior. In: Seminar Proceedings: Influence of the Design of Housing Systems for Cattle on Lameness and on Behavior. Brussels, 1986 June 3-4. Amsterdam, The Netherlands: Martinus Nijhoff; 1987.

116. Kirchner M. Behavioral studies to determine the area requirement of store bulls in slatted floor boxes. KTBL-Schrift. 1986;311:107-115.

117. Kirchner M. Pens with slatted floors for fattening bulls. In Dodd VA, Grace PM, editors. Proceedings of the Eleventh International Congress on Agricultural Engineering. Dublin, Ireland, 1989 September 4-8. Rotterdam: AA Balkema; 1989.

118. Müller C, Ladewig C, Schlichting MC, Thielscher HH, Smidt D. Behavioral and ethological criteria for assessing possible stress factors arising from flooring and density of heifers in group housing. KTBLSchrift. 1986;311:37-47.

119. Graf BP. Influence of various loose-housing systems on beef cattle behavior. 282. PhD Thesis. 1984. Eidg. ForschungsAnstalt für Betribswirtschaft u. Landtechnik, 8355 Tänikon, Switzerland.

120. Kondo S, Sekine J, Okubo M, Asahida Y. The effect of group size and space allowance on the agonistic and spacing behavior of cattle. Appl Anim Behav Sci. 1989;24:127-135.

121. Nielsen LH, Mogensen L, Krohn C, Hindhede J, Sørensen JT. Resting and social behavior of dairy heifers housed in slatted floor pens with different sized bedded lying areas. Appl Anim Behav Sci. 1997;54:307-316.

122. Baxter MR. The space requirements of housed livestock. In: Phillips C, Piggins D, editors. Farm Animals and the Environment. Wallingford, UK: CAB International; 1992.

123. Hafez ESE, Bouissou MF. The behavior of cattle. In: Hafez ESE. The Behavior of Domestic Animals. 3rd ed. Philadelphia, PA: Lippincott Williams and Wilson; 1975.

124. Hurnik JF. Welfare of farm animals. Appl Anim Behav Sci. 1988;20:105-117.

125. Stricklin WR, Graves HB, Wilson LL, et al. Social organization among young beef cattle in confinement. Appl Anim Ethol. 1980;6:211-219.

126. Lutz P, Bogner H, Suss M, Peschke W, Fusseder J. Ethological investigations into the ratio of number of animals to feeding places for young fattening bulls within loose housing. Tierzuchter. 1982;34:414-416. 
127. Grasso F, Napolitano F, De Rosa G, Quarantelli T, Serpe L, Bordi A. Effect of pen size on behavioral, endocrine and immune responses of water buffalo (Bubalus bubalis) calves. J Anim Sci. 1999;77:2039-2046.

128. Amsterdam A, Tajima K, Sasson R. Cell specific regulation of apoptosis by glucocorticoids: Implication to their anti-inflammatory action. Biochem Pharmacol. 2002;64:843-850.

129. Riccardi C, Bruscoli S, Migliorati G. Molecular mechanisms of immunomodulatory activity of glucocorticoids. Pharm Res. 2002;45:361-368.

130. Petrovsky N. Towards a unified model of neuroendocrine-immune interaction. Immun. Cell Biol. 2002;79:350-357.

131. Saha B, Mondal AC, Majumder J, Basu S, Dasgupta PS. Physiological concentrations of dopamine inhibit the proliferation and cytotoxicity of human CD4 and CD8 T cells in vitro: A receptor-mediated mechanism. Neuroimmunomodulation. 200;9:23-33.
132. Saama PM, Jacob JB, Kehrli ME Jr, et al. Genetic variation in bovine mononuclear leukocyte responses to dexamethasone. J Dairy Sci. 2005;87:392.

133. Eriksen HR, Olff M, Murison R, Ursin H. The time dependent dimension in stress responses: Relevance for survival and health. Psychiatry Res.1999;85:39-50.

134. Galon J, Franchimont D, Hiroi N, et al. Gene profiling reveals unknown enhancing and suppressive actions of glucocorticoids on immune cells. FASEB J. 2002;62:61-71.

135. Sorrells SF, Sapolsky RM. An inflammatory review of glucocorticoid actions in the CNS. Brain Behav Immun. 2007;21:259-272.

\section{Publish your work in this journal}

Open Access Animal Physiology is an international, peer-reviewed, open access journal publishing original research, reports, reviews and commentaries on all areas of animal physiology. The manuscript management system is completely online and includes a very

\section{Dovepress}

quick and fair peer-review system. Visit http://www.dovepress.com/ testimonials.php to read real quotes from published authors. 